\title{
Analysis of Graduate Level Principal Preparation and Teacher Preparation Candidates on a Christian Leadership Survey at an American Private Christian University
}

\author{
Glenn L. Koonce, Ed.D. \\ Kurt Kreassig, Ed.D. \\ John Hanes, PhD
}

Regent University, United States of America

Doi: 10.19044/ejes.v5no1a4 URL:http://dx.doi.org/10.19044/ejes.v5no1a4

\begin{abstract}
Universities are seeking ways to measure seemingly subjective experiences of faith, objectively. This study focuses on the measurement of student perceptions of attributes of their Christian leadership development in a university in the mid-eastern part of the United States. Pre-program and postprogram survey responses were collected from students enrolled in educational leadership endorsement and teacher licensure programs from January 2010 through December 2016. Dependent sample t- test showed a fairly normal distribution with three extreme outliers in the difference scores. With alpha set at 0.05 , seven of the nine reviewed categories from the Christian Leadership Survey yielded statistically significant results. These results are tempered by the generally low effect sizes as measured by Cohen's $d$. Recommendations, as a result of this study, are focused on the commitment to continuous improvement in program practices and requirements found in the accreditation standards.
\end{abstract}

Keywords: Christian Leadership Survey, Christian Worldview, Conceptual Framework.

\section{Introduction}

"A Christian college should be an education that cultivates the creative and active integration of faith and learning, of faith and culture. This is its unique task in higher education ... to retain a unifying Christian worldview" (Holmes, 1975, p. 6 - 7). As a center of Christian thought and action, Regent University's (RU) educational leadership and teacher preparation programs' goal is to blend faith and learning principles through integration of the School 
of Education's (SOE) Conceptual Framework (Appendix 1) with the full academic curriculum. Four pillars are found in this framework where students seek knowledge and wisdom in order to serve and edify others in their respective professional learning communities. Servant leadership exemplifies the SOE Conceptual Framework and is a focus in school leadership and teacher preparation

programs.

A true servant leader puts others ahead of his/her own agenda, possesses the confidence to serve, initiates service to others, is not positionconscious, and serves out of love. Servant leadership ministers to individual needs by setting the stage for developing caring leaders and teachers (Maxwell,

The Regent University School of Education (SOE) faculty created the Conceptual Framework in 2001 to capture the essence of its guiding philosophy and orientation. Four pillars were established to encourage its students to:

- Seek knowledge by formulating questions and answers to current educational issues and by formulating research-based solutions,

- Seek wisdom by applying acquired knowledge in a manner that demonstrates a God-given wisdom to create an environment in which justice, human dignity, and academic achievement are valued,

- Serve others by treating them with dignity, love, and respect as well as supporting and encouraging them, and

- Edify others by demonstrating awareness of and sensitivity to the individual needs of their students, colleagues, and community by growing in competence and character (Regent University, 2003, p. 1).

- The essence of the SOE's Christian mission is expressed in the center of its conceptual framework which is acknowledging the centrality of Jesus Christ in all things. All SOE programs contain elements of the conceptual framework and there is an expectation that faculty integrate faith and learning in all courses using this framework. There is a need to assess this integration's impact on student's Christian leadership development. It is the results from this assessment that this study is undertaken. This study provides an American focus on Christian principles and professional formation that may be of interest to the Europen university community.

\section{Continuous Program Improvement}

In education, the term continuous improvement refers to any schoolor instructional-improvement process that unfolds progressively, that does not have a fixed or predetermined end point, and that is sustained over extended periods of time. The concept also encompasses the general belief that improvement is not something that starts and stops, but it's something that 
requires an organizational or professional commitment to an ongoing process of learning, self-reflection, adaptation, and growth. For example, when a school is continuously improving, a variety of small, incremental changes are occurring daily and in ways that cumulatively, over time, affect multiple dimensions of a school or school system. (Great Schools Partnership, 2017, p. 1) Continuous improvement in the university is a relatively dynamic process, and efforts to improve teacher quality at the university level involve faculty analyzing data such as student scores on program assessments, e.g., Praxis II, and various institutionally created instruments. These instruments are used to capture a candidates' teaching and leadership proficiency during coursework and field experiences. Supporting data are typically administered, collected, and analyzed as students move through a university program. The data-driven decision-making that occurs at the program level for faculty is routinely documented for national accreditation purposes. Accrediting organizations demand a culture of evidence for program improvement (Council for the Accreditation of Educator Preparation Handbook, 2015). Program faculty analyze the Christian Leadership Survey data during the academic year to determine if there is a correlation between faculty instruction, program content, and student responses in the nine survey categories: Analytical/Problem Solving Skills, Communication, Christian Worldview, Seeking Wisdom Through Relationships, Discerning Call, Lifestyle Choices, Serving Others Through Christ-like Attributes, Serving Others in the Greater Community, and Edifying Others. Faculty routinely use the data that is disaggregated by each university program to make decisions on adjusting and strengthening curriculum and the integration of biblical principles. The improvements faculty undertake based on student and program data might include changes to course curriculum, field placements, and program logistics. Ultimately these improvements have one purpose, to develop a more effective teacher or administrator.

\section{Statement of the Problem}

Christian colleges and universities are pressed to be faithful to their religious mission being called to preserve and promulgate traditional theological values and practices. A gap in the literature exists for Christian universities and colleges in determining mission impact.

The gap exists in how Christian universities and colleges construct and develop Christian mission impact assessment instruments. No evidence was found in the literature that Christian universities and colleges construct such an assessment instrument based on their school or program conceptual framework. Additionally, Regent University has utilized a Christian Leadership Survey for ten years with very little analysis on program impact. 


\section{Definition of Terms Christian worldview.}

According to Watson (2007), a biblical worldview uses scripture "to assist in developing a framework of conviction that can be applied to various settings. Scripture is to guide the conscious development of our thinking about life and practice" (p. 361).

\section{Regent University Mission Statement.}

Regent University Mission Statement is to train Christian leaders to change the world. As a center of Christian thought and action, RUSOE's goal is to blend faith and learning principles through integration of the School of Education's Conceptual Framework (Regent University, 2017).

\section{Literature Review}

Christian colleges and universities operate under a distinctive set of conditions within American higher education. "They are deeply embedded in and accountable to two worlds, each of which has a distinctive culture: higher education and the church. Both higher education and communities of faith have well-articulated values, expectations, and ways of operation, with each claiming its unique role in influencing administration and academics in Christian institutions of higher education" (Henck, 2011, p. 196). The challenge for Christian universities and colleges is to demonstrate fidelity in both arenas. In one arena, accrediting organizations have prescribed performance standards that universities and colleges must satisfy through periodic accreditation. In the other arena (and the basis for this study), Christian universities and colleges must hold true to their Christian Mission and student worldview impact which have their own performance standards.

Effectively capturing quantitative data in this latter arena can be challenging for Christian university faculty. Noting the absence in the literature of systematic processes or instrumentation used by Christian universities and colleges to capture the Christian Mission impact with fidelity, this study is designed to gather data on program graduates' perceptions of their Christian formation while at Regent University. Operationally, analysis of the data will provide insight into use of the Christian Leadership Survey for program improvement and accreditation.

\section{Christian Worldview}

Christian universities are continually seeking more effective ways to measure graduate performance and outcomes while maintaining their Christcentric Mission focus. Christian universities across America recognize the importance of students developing a steadfast biblical worldview during their college years, and faith integration in Christian academe is the chief topic among American Christian colleges and universities. Watson (2007) found 
that the intention of Christian postsecondary education was to assist students in establishing a framework of beliefs that undergirded every facet of life. The worldviews of twenty-first century university students have been influenced by their fluctuating ideological and demographic backgrounds; today's college campuses represent a diverse population possessing a plethora of worldviews (Coll \& Draves, 2008). Measuring worldview program impact of students should be common practice in Christian universities and colleges in order to gauge intuitional effectiveness.

In reviewing the literature and previous research on the topic of Christian worldview, much uncertainty surrounds research on the perceptions of Christian university graduates' worldview and on the instruments used that contain elements that are germane to measure spiritual growth or perception of Christian worldview (Baniszewski, 2016; Camp, 2009; Morales, 2013). The literature reported a concerted effort to better define the Christian world-view (Sire, 2004; Schultz \& Swezey, 2013) including increased use and study of the Three-Dimensional Worldview Survey-Form C (3DWS-Form C). The focus is its potential use in postsecondary Christian institutions (Morales, 2013). This particular instrument differs from other worldview instruments in that it purports to measure three components of a person's worldview: propositions, behaviors, and heart orientation. In a recent study, the survey was used on over 3600 first year Liberty University students (Morales, 2013). Overall however, the researchers found little commonality in the literature on Christian universities and colleges developing, implementing, and evaluating Christian Mission student-learning outcomes for program improvement and accreditation purposes. As Liu (2011) suggested, institutional differences may create "differential implications" for learning-outcome data (p.7).

Some universities and colleges collect data on what is called, "heartorientation" of its graduates, which is the most recently added component to worldview literature (Schultz, 2013, p. 236), The researcher's did not find any Christian university explicitly linking Christian mission impact assessment instruments to their organizational conceptual framework.

\section{Conceptual Framework}

A conceptual framework is the system of concepts, assumptions, expectations, and beliefs that supports and informs an organization (Miles \& Huberman, 1994; Robson, 2011). Miles and Huberman (1994) further defined a conceptual framework as a visual or written product, one that "explains, either graphically or in narrative form, the main things to be studied - the key factors, concepts, or variables - and the presumed relationships among them" (p. 18). As noted, Regent University's conceptual framework captures the essence of the guiding philosophy and orientation of all of the programs in the SOE. The faculty developed four pillars in this 
framework to achieve the mission of the university and the school. The pillars are evident in all programs including the ones addressed in this study.

\section{Summary}

Christian universities are accountable to two worlds: the Church and higher education regulations. For the Church the accountability measure is an assessment of Christian Worldview. As used in this study, the Church represents the general American evangelical, orthodox, foundational understanding of Christianity illustrated by Regent University's Statement of Faith (Appendix B). This study is part of the SOE's effort to hold itself accountable in light of this statement.

Higher education in RUSOE school leadership and teacher preparation programs are accountable to both the state and the national accreditating agencies for program and accreditor standards. Effectively capturing quantitative data in both arenas is challenging. This study focuses on the measurement of student perceptions of attributes of their Christian leadership development in a university in the mid-eastern part of the United States.

\section{Methodology}

\section{Research Question and Null Hypotheses}

What is the self-perceived impact of six graduate level education programs on the aquisition of Christian principles and professional formation for each program's completer. The associated null hypotheses take the general form of: there is no statistically significant $($ alpha $=0.05)$ difference between student pre-program and post-program scores on the Christian Leadership Survey (CLS) for nine reviewed categories.

\section{Setting}

Data was collected from students enrolled in educational leadership endorsement and teacher licensure programs from January 2010 through December 2016. The six educator preparation programs studied are heavily influenced and guided by state and national accreditation standards. Under national accreditation measures, each program undergoes a voluntary process for assessing and enhancing academic and educational quality. The process assures coursework and faculty quality and supports continuous improvement throughout the university. The programs: Elementary Education, Special Education, Reading, Career Switcher, Teaching English to Students of Other Languages (TESOL) and Educational Leadership all follow strict mandates set forth by the state. Each program awards a license or certificate to program completers in the area or discipline studied as noted in Table 1. 


\section{Table 1}

Distinguishing Features of the Elementary Education, Special Education, Gifted Education, Reading Specialist, Career Switcher, TESOL Programs, and Educational Leadership

\begin{tabular}{|c|c|c|c|c|}
\hline $\begin{array}{l}\text { Program } \\
\text { Name }\end{array}$ & $\begin{array}{l}\text { Degree } \\
\text { Status }\end{array}$ & Length & Results & Features \\
\hline $\begin{array}{l}\text { Elementary } \\
\text { Education }\end{array}$ & $\begin{array}{l}\text { Bachelor of } \\
\text { Science } \\
\text { (B.,S.) in } \\
\text { Interdisciplin } \\
\text { ary Studies } \\
\text { (IDS) } \\
\text { or } \\
\text { Master's in } \\
\text { Education } \\
\text { (M.Ed.) }\end{array}$ & 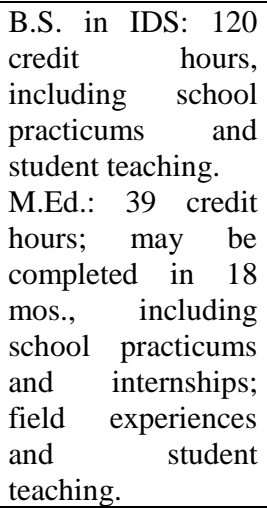 & $\begin{array}{l}\text { Bachelor of } \\
\text { Science in IDS and } \\
\text { Initial Teacher's } \\
\text { Licensure PreK-6. } \\
\text { Master Of of } \\
\text { Education degree } \\
\text { and Elementary } \\
\text { Education Initial } \\
\text { Teacher's License } \\
\text { PreK-6. }\end{array}$ & $\begin{array}{l}100 \text { hrs. of field } \\
\text { experiences/obse } \\
\text { rvations } \\
\text { (Practicum) } \\
\text { and } \\
500 \text { hrs. of } \\
\text { internship } \\
\text { experience }\end{array}$ \\
\hline $\begin{array}{l}\text { Special } \\
\text { Education }\end{array}$ & $\begin{array}{l}\text { Master's in } \\
\text { Education } \\
\text { (M.Ed.) } \\
\text { or } \\
\text { Professional } \\
\text { Developmen } \\
t\end{array}$ & $\begin{array}{l}35-38 \text { credit hours; } \\
\text { may be completed } \\
\text { in } 18-24 \text { mos.; one } \\
\text { semester may be } \\
\text { added for Reading } \\
\text { Specialist } \\
\text { Endorsement. }\end{array}$ & $\begin{array}{lr}\text { Master } & \text { of } \\
\text { Education degree } \\
\text { and initial K-12 } \\
\text { teacher licensure } \\
\text { with endorsement } \\
\text { in Sped Gen Curr. } \\
\text { K12 and/or } \\
\text { Reading } \\
\text { Specialist. }\end{array}$ & $\begin{array}{l}310 \text { hrs. of } \\
\text { internship in each } \\
\text { area of } \\
\text { endorsement; } \\
\text { practitioner- } \\
\text { oriented. }\end{array}$ \\
\hline $\begin{array}{l}\text { Reading } \\
\text { Specialist }\end{array}$ & $\begin{array}{l}\text { Master's in } \\
\text { Education } \\
\text { (M.Ed.) }\end{array}$ & $\begin{array}{l}37 \text { credit hours. } \\
\text { May be completed } \\
\text { in } 18-24 \text { months. }\end{array}$ & $\begin{array}{l}\text { Master of } \\
\text { Education degree } \\
\text { and Reading } \\
\text { Specialist } \\
\text { endorsement. }\end{array}$ & $\begin{array}{l}\text { This program } \\
\text { features } \\
\text { increased } \\
\text { flexibility with } \\
\text { an online } \\
\text { delivery, while } \\
\text { maintaining a } \\
\text { very practical } \\
\text { and engaging } \\
\text { approach to } \\
\text { learning. }\end{array}$ \\
\hline $\begin{array}{l}\text { Career } \\
\text { Switcher }\end{array}$ & Non-degree & $\begin{array}{l}24 \text { credit hours. } \\
\text { May be completed } \\
\text { in } 16-24 \text { mos.; } 1 \text { yr. } \\
\text { mentored teaching } \\
\text { required. }\end{array}$ & 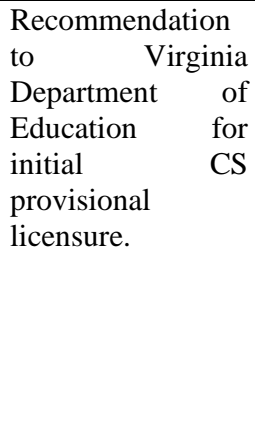 & $\begin{array}{l}\text { Provides mentor } \\
\text { support for } \\
\text { students in the } \\
\text { classroom; } \\
\text { includes 1 yr. } \\
\text { mentored } \\
\text { teaching during } \\
\text { Level II } \\
\text { experience; may } \\
\text { add } 14 \text { credit hrs. } \\
\text { to earn a Master's } \\
\text { in Education. }\end{array}$ \\
\hline
\end{tabular}




\begin{tabular}{|c|c|c|c|c|}
\hline $\begin{array}{l}\text { TESOL } \\
\text { (ESL Pre-K } \\
-12 \\
\text { Endorseme } \\
\text { nt track }\end{array}$ & $\begin{array}{l}\text { Endorsement } \\
\text {, but may be } \\
\text { added to a } \\
\text { Master's in } \\
\text { Education } \\
\text { (M.Ed.) } \\
\text { program. }\end{array}$ & $\begin{array}{l}32 \text { credit hours for } \\
\text { master's degree; } \\
\text { may be completed } \\
\text { in } 18 \text { mos.; } 15 \\
\text { credit hours for } \\
\text { certificate only. }\end{array}$ & $\begin{array}{l}\text { Master of } \\
\text { Education degree } \\
\text { and/or } \\
\text { recommendation } \\
\text { for ESL PreK-12 } \\
\text { endorsement. }\end{array}$ & $\begin{array}{l}\text { Pre-K-12 } \\
\text { Endorsement } \\
\text { track. }\end{array}$ \\
\hline $\begin{array}{l}\text { Educational } \\
\text { Leadership }\end{array}$ & $\begin{array}{l}\text { Master's in } \\
\text { Educational } \\
\text { Leadership }\end{array}$ & $\begin{array}{l}\text { M.Ed.: } 37 \text { credit } \\
\text { hours; may be } \\
\text { completed in } 18 \\
\text { mos. including } \\
\text { internships }\end{array}$ & $\begin{array}{ll}\text { Master } & \text { of } \\
\text { Education } & \text { in } \\
\text { Educational } & \\
\text { Leadership } & \end{array}$ & $\begin{array}{l}320 \text { hrs. of } \\
\text { internship } \\
\text { experience }\end{array}$ \\
\hline
\end{tabular}

\section{Population}

The total number of educational leadership endorsement and teacher licensure program enrollees was 4435 during the timeframe studied and data are disaggregated by program and year (Table 2). The figure of 4435 represents the potential of 4435 program enrollees who could have taken the survey. The survey is delivered online to all students when they enter their respective program and a second time upon program completion. Table 3 displays the number of CLS per Survey Monkey Dataset, Survey Monkey being the delivery tool for the CLS.

\section{Table 2}

Total Number of students enrolled in the Elementary Education, Special Education, Reading, Career Switcher, TESOL, Educational Leadership Programs who had potential to take the survey (2010-2016)

\begin{tabular}{ccccccccc}
\hline Program & 2010 & 2011 & 2012 & 2013 & 2014 & 2015 & 2016 & Total \\
\hline *Elementary & 22 & 21 & 13 & 10 & 10 & 5 & 10 & 91 \\
$*$ Special & 145 & 170 & 185 & 189 & 201 & 217 & 233 & 1340 \\
$\begin{array}{c}\text { Education } \\
\text { *Reading }\end{array}$ & 24 & 72 & 91 & 73 & 78 & 72 & 64 & 474 \\
$\begin{array}{l}\text { Specialist } \\
\text { *Career }\end{array}$ & 106 & 99 & 110 & 99 & 123 & 157 & 167 & 861 \\
$\quad$ Switcher & & & & & & & & \\
*TESOL & 74 & 70 & 57 & 67 & 72 & 95 & 103 & 537 \\
*Educational & 132 & 157 & 171 & 160 & 160 & 175 & 176 & 1131 \\
Leadership & & & & & & & & \\
Total & 503 & 589 & 627 & 598 & 644 & 721 & 753 & 4435 \\
\hline
\end{tabular}


Table 3

Number of Christian Leadership Surveys per Survey Monkey Dataset Analyzed from 01/01/2010-12/4/2016

\begin{tabular}{ll}
\hline Dataset Name & Number of surveys analyzed per dataset \\
\hline A & 40 \\
B & 46 \\
C & 298 \\
D & 511 \\
E & 1336 \\
F & 1851 \\
\hline Total & 4082 \\
\hline
\end{tabular}

\section{Instrument}

The CLS is an integral part of the ongoing process of enhancing and improving student outcomes and in preparing them to transform lives in their careers and communities. This program level assessment helps students evaluate and reflect on their level of readiness for Christian leadership. Through a review of the literature, review of other instruments such as Benson \& Erickson's Faith Maturity Scale (1993), the faculty's experiences, expert panel, and personal beliefs on faith, 45 questions (Table 4) were developed around each of the 5 outcomes clustered in themes for each section: Seeking Knowledge through Scholarly Inquiry, Seeking Wisdom, Serving Others, Edifying Others, and Faculty and Staff Integration of Values.

The fifth section on Faculty and Staff Integration was added in later years to confirm if faculty and staff were perceived to demonstrate the values espoused to their graduates. Because the fifth theme of Faculty and Staff was not stable across the timeframe studied by the researchers, it was not included in this research project. The method of scaling the questionnaire was a five point fully anchored Likert - type scale $\{1$ (Never True of me) to 5 (Always True of me)\}. Among the 5 major domains/themes each contained subcategories which defined or reflected an operational definition for application. For example, seeking knowledge contained 9 questions that addressed subcategories of Analytical Problem Solving Skills and Communication (Table 4). 
Table 4

Number of Questions per Category Analyzed

\begin{tabular}{ll}
\hline Category & Number of questions per category \\
\hline Analytical/Problem Solving Skills & 5 \\
Communication & 3 \\
Christian Worldview & 2 \\
Seeking Wisdom Through Relationships & 3 \\
Discerning Call & 5 \\
Lifestyle Choices & 5 \\
Serving Others Through Christ-like Attributes & 8 \\
Serving Others in the Greater Community & 5 \\
Edifying Others & 9 \\
\hline Total & 45
\end{tabular}

Some of the actual program features being assessed by the Christian Leadership Survey include faith and learning assignments in each course, BlackBoard forums, paper assignments, residency where applicable, personal communication with faculty, availability of chapel services on campus or on the internet, ambience of the Regent University website including Bible verses of the day and commentary, prayer requests on BlackBoard, choice of texbooks, reading assignments in courses, and student services with faith based activities and resources. This list is not all inclusive as there are numerous other program features and characteristics that are elements of student life at the university. Upon completion of this study additional steps will be recommended to develop students in the area of Christian principles and professional formation.

The face validity of the CLS is strong since the items were directly generated from the SOE conceptual framework. The framework is described in every course syllabus and the faculty discusses how the framework applies to the respective courses. According to Hopkins and Hanes (2010), validity measures for the CLS include content validity, criterion-related validity, and construct validity. Content validity mirrors face validity noting the items from the survey are derived from the conceptual framework, support for it in the research literature, developed by a single professor with 12 years' experience in the SOE, and the entire faculty reviewed and had opportunity to comment on it. Criterion-related validity, concurrent, from a large scale pilot test and although anonymity maintained, it can still compare for trends via school specific cohorts and predictive in that it can be compared to the RU SOE Alumni Survey which elicits information about activities and awards and cohorts. Construct validity results from four factors (factor analysis): (1) Kaiser-Meyer-Olkin measure of Sampling Adequacy is .96 and Bartlett's Test of sphericity yields an approximate chi-square of 18880.09, $\mathrm{p}<.001$; (2) ChiSquare Goodness-of-fit Test produces a value of 4056.15, $\mathrm{p}<.001$ and percent of Total Variance Explained is 49.54, thus roughly half of the variance in the 
data is explained by four factors - researchers would like for this to be higher but accept the 49.54; (3) the Scree Plot indicates 4 Factors, 11 factors have Eigenvalues > 1, Kaiser-Guttman Rule dictates inclusion of these, an 'Eigenvalue is the proportion of variance explained by each factor', interpretability is a major issue with 11 factors, and 11 factors explain $66.01 \%$ of the variance"; (4) the structure matrix indicates that many items loaded on Factor 1 across 3 of the pillar scales, the Seeking Knowledge pillar items loaded on Factor 4 with good separation, no other pillar scale provided such sound loadings, Factor 2 loaded negatively for all items, 14 of which had predominant loadings here, and Factor loadings are the correlation coefficients between variables (items) and factors. (slides 17-28).

The CLS was administered to all students in their first program course (Blackboard Introduction) and again in their last program course or capstone course. The administration of the survey was accomplished through a Survey Monkey link in the students' Blackboard Introduction course, through course syllabi postings, and routine faculty course announcements alerting students to complete the survey. In recent years the CLS has been a leading topic among RUSOE faculty as accreditation metrics were analyzed. Faculty have methodically cataloged each program course offering the survey to students in order to increase student awareness of the survey and increase return rates. Although some variability exists among the means of the various administrations of the survey, this variability is small and due primarily to a ceiling effect. The internal reliability of the CLS, measured by coefficient alpha is .94 for 2009-2013 surveys and .95 for the 2013-2014 administrations. These findings are a respectable indicator of internal consistency for the administrations of the instrument.

A sample of CLS questions are presented in Figure 1 to provide context to the instrument used for data collection. Five sample questions are noted with the likert-type ratings as they appear in Survey Monkey.

\section{Analysis of the Christian Leadership Survey}

During the spring and summer of 2006 and the fall of 2007, faculty set out to probe hypothesis based on the CLS to determine the impact RUSOE had in fulfilling its mission "to

Figure 1 Sample of Christian Leadership Survey Questions

Analytical /Problem Solving Skills

I think critically about Not true of me Rarely true of me Sometimes true of me Usually true of me Always true of me

important questions in

my field of study.

Christian

Worldview

I understand the

Usually true of me

Not true of me

Rarely true of me

Always true of me

Sometimes true of me 
meaning of the term

"biblical worldview" and

its application to life.

Seeking

Wisdom

through

Relationship

I accept persons whose Not true of me Rarely true of me Sometimes true of me

Usually true of me Always true of me

opinions differ from

mine.

Discerning

Call

I am aware of my God- Not true of me Rarely true of me Sometimes true of me

Usually true of me Always true of me

given talents and

abilities.

Serving Others through Christ-like Attributes

I speak truth in love. Not true of me Rarely true of me Sometimes true of me

Usually true of me Always true of me

provide exemplary education, from a biblical perspective..." Eleven hypotheses based on the means of the pre-enrollment survey versus the means of the post-program survey categories from a small sample population were analyzed by the faculty. Faculty sought to determine if there was a statistically significance difference between the pre and post averages. Faculty concluded that there was evidence to imply a difference in the scores among students. The finding that supported "program training and attributes" probably had an impact in the area of Christian Worldview given the differences in the scores from the pre-enrollment survey and the post-program survey provided confidence to faculty that they are providing a biblically based, Christian education in line with the school's conceptual framework. All other hypotheses were not statistically significant. At the time, this was disappointing considering the programs were intended to impact those dimensions as well. Based on data, faculty and respondent feedback, the CLS underwent several modifications over the last ten years. Faculty in the School of Education routinely review annual CLS data by faculty and department for accreditation purposes. Feedback is solicited from faculty and documented during faculty department meetings. Although the survey has undergone modifications over ten years, nine categories noted in Table 6 and related categorical questions and the Likert Scales remained constant during the period of 
Table 6

Stable Christian Leadership Survey Categories

Name of Category

Analytical/Problem Solving Skills

Communication

Christian Worldview

Seeking Wisdom Through Relationships

Discerning Call

Lifestyle Choices

Serving Others Through Christ-like Attributes

Serving Others in the Greater Community

Edifying Others

serve others and view leading or teaching as an edifying process for their staff and/or their students.

\section{Procedures}

All students in teacher licensure and educational leadership endorsement programs are surveyed in their initial Blackboard course and again in the last program course they take. Data is stored with and reported by the RUSOE Data Manager for review by the educational leadership endorsement and teacher licensure faculty.

\section{Data Mining}

The researchers took steps to appropriately document data cleaning and preparation processes so the data can be used accurately by colleagues and other researchers in the future. Researchers utilized the strengths of Microsoft Excel to capture, sort, and clean the data.

The documentation of the data cleaning process provided identifiable and usable data derived from the workflow described.

Several survey questions were slightly modified by faculty for clarification purposes over six years and the survey was used across all programs and available to all enrollees of teacher licensure and educational leadership programs. The university utilized the Survey Monkey database for all surveys in this study and the survey instrument was administered online to students during their first and last program courses. Six Survey Monkey datasets were analyzed dating from January 1, 2010 through December 4, 2016. The number of surveys analyzed per Survey Monkey dataset within the selected date range is displayed in Table 3. Respondent dates of survey completion varied depending on the semester enrolled and semester of completion in their respective programs. The six Survey Monkey datasets were not assigned to particular programs during the administration of the survey. It was determined by the researchers that assignment of the Survey Monkey dataset survey web link provided to each program enrollee was 
unsystematically performed by university personnel. The six Survey Monkey datasets contain respondents from every teacher licensure and educational leadership program. Occasionally, student survey data was identified to belong to more than one dataset (A-G) among the six datasets. Again, this was most likely due to the unsystematic process of assigning survey web links.

The researchers chose the date range of January 2010 through December 2016 to coincide with the ongoing School of Education accreditation data analysis. The CLS Likert scale remained constant over the five year period studied. Several survey questions underwent minor clarifications or were removed during that timeframe by faculty. For example, in the category Analytical/Problem Solving, question one was slightly modified from: I formulate questions and answers that demonstrate critical thinking and reflection to I think critically about important questions in my field of study. Question three in the same category was slightly modified from: I read scholarly articles to refine my professional knowledge and skills to I read scholarly journals and articles to refine my professional knowledge and skills.

Two questions in the category Seeking Wisdom through Relationship were removed: I express my point of view and actively listened to others' point of view and I empathize with others even though their beliefs and culture may be different from my own. These modifications were suggested and completed by faculty during the School of Education Accreditation and Accountability monthly meetings in order to improve survey face and construct validity.

The researcher's goal was to analyze pre-program and post-program survey data for each program completer which would produce usable data to help program faculty make program improvement decisions. Data sets were cleaned and prepared using Microsoft Excel. The researchers utilized a phased approach that produced analysis-ready data without destroying the original data sets (Weiss \& Townsend, 2005).

The researchers began with a total of 4082 student surveys in six Survey Monkey datasets dating from January 1, 2010 through December 4, 2016. The intent was to preserve the meaningful pre-program and postprogram data for each program completer while removing elements of the datasets that would affect the quality of the results. With a total number of program enrollees of 4435 and the potential of 8870 responses, this yielded the researchers with an initial return rate of $46 \%$. The intention was to identify two surveys per student; one pre-program survey and one post-program survey. Single respondent and incomplete survey data (incomplete survey defined as less than half of the questions completed) were removed which refined the total to 3102 student surveys. Single respondent surveys might be due to the nature of a volunteer survey with some students only completing either the pre-program or post-program CLS during their program. The data 
was further refined using survey completion date and corresponding respondent name or student ID number to find and remove duplicate entries of preprogram and/or post-program surveys from the same respondent. This duplicate data was widespread throughout all Survey Monkey datasets and the phenomenon appeared to be respondent submission errors caused by repeatedly submitting completed survey data during the same session, thus sometimes producing two identical pre-program and/or two identical postprogram surveys for a respondent. These actions produced a total respondent corresponding pre-program and post-program survey number to 1068. The researchers reported 534 students enrolled in a Teacher Licensure or School Leadership Program with a pre-program score and a post-program score for the CLS from January 1, 2010 through December 4, 2016. This provided the researchers with a final return rate of $12 \%$ for the two completed surveys per student identified in the study, see Table 7.

Table 7

Participation

\begin{tabular}{lll}
\hline Surveys & $\begin{array}{l}\text { Reason for Survey } \\
\text { Removal }\end{array}$ & Number of Students \\
\hline 8870 Potential for Return & - & 4435 enrolled in SOE Programs \\
4082 Returned & $\begin{array}{l}\text { Non-participation } \\
\text { Single }\end{array}$ & - \\
3102 after first exclusion & $\begin{array}{l}\text { response/incomplete } \\
\text { Duplicate/multiple } \\
\text { entries }\end{array}$ & - \\
exclusion & & 534 complete pre-post entries \\
\hline
\end{tabular}

The researchers calculated the pre-program and post-program gain scores for each question within the nine identified categories. Random hand calculations of survey mean scores and gain scores were conducted by the researchers to verify data processing accuracy.

\section{Limitations}

The first limitation is that the responders self-report their perceptions, and survey data should be viewed in conjunction with other assessment results to determine the program's effectiveness in developing caring and skilled teachers. Another limitation is the survey return rate. Although students are provided the CLS during their first and last program courses and consistently reminded to participate in the survey by staff and faculty, the survey is voluntary.

\section{Results}

Table 8 summarizes the results for analyses using the dependent samples $t$-test to determine whether a statistically significant difference exists for each of the nine categories selected for review. The assumption of 
normality for the difference scores was tested using the Kolmogorov-Smirnov test with Lilliefors correction, and the overall test result was statistically significant, D (534) $=0.05, \mathrm{p}<.01$. A histogram showed a fairly normal distribution, but three extreme outliers were present in the difference scores. With larger sample sizes, $\mathrm{N}>30$, the dependent samples t-test tends to be robust to mild to moderate violations of normality (Rovai, Baker, \& Ponton, 2014).

For the null hypotheses that there is no statistically significant difference between the pre-program survey and the post-program survey, most of the $t$-tests were statistically significant with alpha set at .05 , and there is sufficient evidence to reject seven of the nine null hypotheses as indicated in Table 8 .

The effect size using Cohen's $d$ is quite low for seven of the categories. By convention, values of $0.2,0.5$, and 0.8 represent low, medium, and high ratings (Rovai, Baker, \& Ponton, 2014). Thus Analytical Problem Solving Skills (0.52) has a medium effect size, and Communication (0.31) has a slightly better than low effect size.

In determining statistical conclusion validity, both statistical and practical significance

\section{Table 8}

Descriptive Statistics and t-test Results for Nine Categories of the Christian Leadership Survey

\begin{tabular}{|c|c|c|c|c|c|c|c|c|c|}
\hline \multirow[b]{2}{*}{ Category } & \multicolumn{2}{|c|}{$\begin{array}{l}\text { Pre- } \\
\text { program }\end{array}$} & \multicolumn{2}{|c|}{$\begin{array}{l}\text { Post- } \\
\text { program }\end{array}$} & \multirow[b]{2}{*}{$\mathrm{n}$} & \multirow[b]{2}{*}{$\begin{array}{l}95 \% \text { CI for } \\
\text { Mean } \\
\text { Difference }\end{array}$} & \multirow[b]{2}{*}{$\begin{array}{l}\text { Ef } \\
\text { fe } \\
\text { ct } \\
\text { si } \\
\text { ze }\end{array}$} & \multirow[b]{2}{*}{$\mathrm{t}$} & \multirow[b]{2}{*}{$\begin{array}{l}\text { Sig. } \\
(2- \\
\text { taile } \\
\text { d) }\end{array}$} \\
\hline & M & SD & M & $\begin{array}{l}\text { S } \\
\text { D }\end{array}$ & & & & & \\
\hline Analytical/P & & & & & & & & & \\
\hline ro-blem & 3. & & 4.1 & .5 & 53 & & .5 & 11.9 & \\
\hline $\begin{array}{l}\text { Solving } \\
\text { Skills }\end{array}$ & 90 & .56 & 8 & 3 & 4 & $.32, .23$ & 2 & $0^{*}$ & .00 \\
\hline Communica & 4. & & 4.3 & .5 & 53 & & .3 & 7.07 & \\
\hline tion & 19 & .57 & 5 & 3 & 4 & $.11, .20$ & 1 & $*$ & .00 \\
\hline Christian & 4. & & 4.4 & .5 & 52 & & .1 & 2.33 & \\
\hline Worldview & 38 & .59 & 4 & 5 & 9 & $.10, .09$ & 0 & $*$ & .05 \\
\hline Seeking & 4. & 57 & 4.4 & .5 & 53 & & .2 & 5.13 & \\
\hline Wisdom & 37 & .57 & 2 & 1 & 1 & $.06, .03$ & 2 & $*$ & .00 \\
\hline Discerning & 4. & & 4.3 & .5 & 53 & & .1 & 3.50 & \\
\hline Call & 24 & .53 & 2 & 0 & 0 & $.03, .12$ & 5 & $*$ & .00 \\
\hline Life-style & 4. & & 4.2 & .4 & 53 & & .0 & & \\
\hline Choices & 24 & .46 & 5 & 6 & 0 & $.03, .04$ & 1 & 0.31 & .74 \\
\hline Serving & 4. & & 4.4 & .4 & 52 & & .1 & 3.11 & \\
\hline Others & 37 & .45 & 3 & 4 & 7 & $.02, .09$ & 4 & $*$ & .00 \\
\hline
\end{tabular}




\begin{tabular}{llllllllll} 
Serving & 4. & & 4.2 & .5 & 52 & $.03, .12$ & .1 & 3.25 & .00 \\
Community & 16 & .56 & 4 & 5 & 7 & & 4 & $*$ & \\
Edify & 4. & .61 & 4.1 & .6 & 52 & $.074, .076$ & .0 & & \\
& 17 & 2 & 7 & 13 & 0 & 02 & .98 \\
\hline
\end{tabular}

provide some essential elements that require evaluation (Johnson \& Christensen, 2014; see Shadish, Cook, \& Campbell, 2002, for additional elements for consideration). Only the

Analytical Problem Solving Skills category reaches statistical conclusion validity for this study.

Note that because of pairwise deletion selection, the degrees of freedom, reflecting the $\mathrm{n}$ size, vary slightly across the categories.

\section{Findings}

\section{Discussion}

With alpha set at 0.05 , seven of the nine reviewed categories from the Christian Leadership Survey yielded statistically significant results. These results are tempered by the generally low effect sizes as measured by Cohen's $d$. The Analytical/Problem Solving Skills category stands out as the only subscale that reaches statistical conclusion validity (Johnson \& Christensen, 2017; $\mathrm{p}<0.01$ and $d=0.52$ ). It also stands out as the only survey category that does not incorporate an element of overt Christian leadership which is the target of this research.

In addition, Analytical/Problem Solving Skills is the only category to have a pre-program mean value of less than 4.00 (3.90 versus a range of 4.16 - 4.38). Likewise, this category had the second lowest post-program mean score (4.18 versus 4.17 for Edify), and it produced the largest gain in mean value ( 0.28 versus 0.16 for Communication); this seems reasonable in light of the previously mentioned ceiling effect.

Another potential influence on the results stems from the clearly Christian character and orientation of Regent University. For the most part, Regent attracts and enrolls professed Christian students who should initially score well on most of the pre-program CLS categories. These students may have little room to grow on such measures as perhaps demonstrated by the post-program survey means and the mean gain values. The Life Styles Choices category offers a good example in this regard. It is not surprising that students with a strong belief in Jesus and His teachings would also have already made certain lifestyle choices in line with these beliefs. Those choices would be supported by the Regent University environment and campus experiences such that mean scores would change very little from pre-program to post-program assessments (in this case a mean gain of 0.01 ). 
Explaining the lack of any mean gain (0.00) for the Edify category is challenging. There appears to be little to distinguish this category from five other "Christian" ones (excluding Life Style Choices, Analytical/Problem Solving Skills, and Communication). Communication lies on the border of a clear Christian emphasis, and this may help explain its second largest effect size of $d=0.31$ and second largest mean gain $=0.16$.

The researchers note that the lack of randomization and a low response rate make the CLS reflect a convenience sample. For this reason, utilization of inferential statistics including $p$-values is open to question. However, effect sizes stand on their own for any particular dataset, and we have emphasized their importance by reporting statistical conclusion validity.

The researchers also acknowledge the threat posed by nine hypothesis tests on the same dataset leading to the need for compensation via the deployment of a familywise alpha to control for a Type I error (Green \& Salkind, 2017). In this first cut at exploration of the CLS, the researchers felt that it was reasonable to treat each of the nine categories as a separate survey, and various control methods (Bonferroni, Holm's Sequential Bonferroni, etc.) were not applied.

Travelling with the nature of a convenience sample, threats to external validity in terms of population, settings, and time are present. The researchers cannot extrapolate to our School of Education student population for the included time period; the researchers can only make conclusions for the limited dataset that was analyzed.

\section{Recommendations for Christian Leadership Survey Practices}

Recommendations, as a result of this study, are focused on the commitment to continuous improvement in program practices and requirements found in the accreditation standards. Therefore, recommendations specifically address CLS outcomes and its administration. First, RUSOE programs should continue to administer the CLS and do so with more precise and accurate evaluation of the results. CLS data provides a measure of Christian leadership and the integration of faith and learning through the program's course of study. Faith and learning is no longer the term used by the university as the university change the focus to Biblical Principles. All references in the CLS and those related to the administration and evaluation of the CLS must utilize this new term. Faculty should continue to highlight Biblical Principles in course learning goals, syllabi, discussion board posts, and other instructional methods.

Additional recommendations are as follows. CLS data should be disaggregated by program, as well as, graduate and undergraduate. Holding more accountability to the various levels of involvement into CLS outcomes could have a dramatic impact on participation. There needs to be specific 
attention to improving the response rate by providing professional development to the faculty, especially adjunct faculty, to educate them on the purposes and administration procedures for the CLS. The faculty should reevaluate the courses where the CLS is administered for optimal participation. Another recommendation and/or strategy for increased participation is to design a video presentation on the CLS for program chairs and other viable individuals who have a voice in its administration. The video could be imbedded in online course modules for all students and faculty to access.

Specific recommendations address program faculty. Program faculty must review the CLS in their committee sessions for any revisions or clarifications. Focus groups of faculty and students should be organized to address specific CLS categories and their use in the CLS for a more in depth review. Faculty should conduct CLS exit interviews with program respondents. Whether face-to-face or online, faculty probing student interactions before, during, and after the course could shed light on the respondent's survey answers. Faculty should hold focus/debriefing sessions before a course begins, during and after the course ends to discuss the premise of Christian Worldview and Biblical Principles. Faculty could better understand student perceptions of Christian Worldview that might not be evident in survey data. Increase opportunities should be provided for students to lead in the discussion and formation of Christian Worldview. SOE faculty who have expertise in Christian leadership formation and/or teaching of Biblical Principals should be called upon to in-service all program faculty regarding their expertise. Finally, upon review and inclusion of all recommendations, a report should be completed and reviewed in detail by all program faculty as evidence of the work to improve the CLS. The report should be submitted to the SOE dean and filed for evidence in accreditation requirements.

Any contemplated adjustments must be brought to the Accreditation and Accountability Team (AAT) for further discussion and approval. It is the AAT that directs the faculty's effort for state program approval and accreditation. The AAT houses the data storage/retrieval system and makes recommendations to the all faculty and or SOE dean for any items that align with program approval and/or national accreditation. Much data mining and analysis has been conducted on the CLS, the researchers encourage its continued use with the recommendations made. To conclude, this study should be presentation to the field for best practices in program approval and accreditation. The researchers felt that submitting this study to a European journal would provide an international perspective for reflection and additional research opportunities. 


\section{References:}

Baniszewski, D. (2016). A causal comparative analysis of biblical worldview among graduate students based on Christian school attendance (Doctoral dissertation). Retrieved from ProQuest. (10110760)

Camp, D. (2009). A survey of the graduates of Christian secondary schools and their beliefs in the effectiveness of the academic and spiritual education Received (Doctoral dissertation). Retrieved from ProQuest. (3401961)

Coll, J. E., \& Draves, P. R. (2008). An Examination of the Relationship between Optimism and Worldview among University Students. College Student Journal, 42(2), 395-401.

Council for the Accreditation of Educator Programs. (2015). CAEP evidence guide version 2.0. from http://caepnet.org/ /media/Files/caep/knowledge-center/caep-evidenceguide.pdf?la=en Great Schools Partnership. (2017). Continuious improvement. Retrieved from http://greatschoolspartnership.org/

Green, S.B., \& Salkind, N.J. (2017). Using SPSS for windows and macintosh: Analyzing and understanding data ( $8^{\text {th }}$ ed.). New York, NY: Pearson.

Henck, A. (2001). Walking the Tightrope: Christian Colleges and Universities in a Time of Change. Christian Higher Education, 10, 196-214.

Holmes, A. (1975). The idea of a Christian college. Grand Rapids, MI: Wm. B. Eerdmans.

Hopkins, J., \& Hanes, J. (2010). The Christian Leadership Assessment Instrument: A Program Accountability and Measurement Tool. Presentation at the Virginia Education Research Association Meeting, Charlottesville, VA. Johnson, R.B., \& Christensen, L. (2017). Educational research: Quantitative, qualitative, and mixed approaches $\left(6^{\text {th }}\right.$ ed.) Los Angeles, CA: Sage.

Liu, O. (2011). Outcomes Assessment in Higher Education: Challenges and Future Research in the Context of the Voluntary System of Accountability. Educational Measurement: Issues and Practice, 30(3), 2-9.

Maxwell, J. (1999). The 21 indispensable qualities of a leader. Nashville, TN: Thomas Nelson.

Miles, M., \& Huberman, A. (1994). Qualitative data analysis (2nd ed.). Thousand Oaks,

CA:

Sage. Morales, K. (2013). An instrument validation for a three-dimensional worldview survey among undergraduate Christian university students using principal components analysis (Doctoral dissertation). Retrieved from ProQuest. (3589627) Regent University, School of Education (2003).

School of Education Conceptual Framework.(2017). Retrieved from http://www.regent.edu/acad/schedul/about/framework.cfm

Robson, C. (2011). Real world research. Chichester, UK: Wiley-Blackwell. 
Schultz, K., \& Swezey, J, (2013). A Three-Dimensional Concept of Worldview. Journal of Research on Christian Education, 22:3, 227-243.

Shadish, W.R., Cook, T.D., \& Cambell, D.T. (2002). Experimental and quasiexperimental designs for generalized causal inference. Boston, MA: Houghton Mifflin.

Sire, J. W. (2004). Naming the elephant: Worldview as a concept. Downer's Grove, IL: InterVarsity

Press.

\section{Appendix A}

Regent University School of Education Conceptual Framework

Regent University, (2017), p. 1. Retrieved from https://www.regent.edu/soe/about/

\section{OUR PURPOSE defined and operationalized:}

Acknowledging the centrality of Christ in all things, the Regent University School of Education commits itself to providing learning opportunities which promote the skills, dispositions and understandings which will enable its graduates to seek knowledge and wisdom in order to serve and edify others. To this end, Regent School of Education graduates will manifest the following characteristics:

SEEKING KNOWLEDGE: The School of Education graduate will...

formulate questions and answers that demonstrate critical

thinking and reflection,

identify research-based solutions for current issues in the field, design and develop frameworks and applications that are

relationship sensitive, and solution oriented, and

demonstrate the scholarly characteristics of a life-long learner.

SEEKING WISDOM: The School of Education graduate will...

demonstrate an understanding of a biblical world view and its

application to learning and life, and

$\square$ apply knowledge in a manner which demonstrates a God-given

wisdom to create a world in which social justice and human

dignity are valued.

SERVING OTHERS: The School of Education graduate will serve others in a Christ like manner by...

speaking the truth in love,

treating others with dignity and respect,

supporting and encouraging others, and

displaying beatitudinal qualities.

EDIFYING OTHERS: The School of Education graduate will... 
inspire the learner to seek knowledge, orient the learner toward a lifelong search for wisdom, and support him/her in that pursuit,

$\square$ enable and encourage the learner to grow in character, and to seek God's call and purpose for his/her life,

$\square$ demonstrate awareness of and sensitivity to the individual needs of their students, colleagues and community, and will strive to meet those needs in love and service, and exemplify a life of faithful service which will encourage others to do likewise.

\section{Appendix B}

Regent University Student Handbook. (effective September 5, 2017) Regent University. (2017), p. 9. Retrieved from https://www.regent.edu/admin/stusrv/docs/StudentHandbook.pdf 2.4. Statement of Faith

2.4.1. Regent University is a Christ-centered institution. The Board of Trustees, along with the faculty, staff and students of the University, are committed to an evangelical interpretation and application of the Christian faith. The campus community is closely identified with the present-day renewal movement, which emphasizes the gifts, fruit, and ministries of the Holy Spirit. All employees are expected to understand and adhere to the following articles of belief:

2.4.1.1. That the Holy Bible is the inspired, infallible, and authoritative source of Christian doctrine and precept.

2.4.1.2. That there is one God, eternally existent in three persons: Father, Son, and Holy Spirit.

2.4.1.3. That man was created in the image of God but, as a result of sin, is lost and powerless to save himself.

2.4.1.4. That the only hope for man is to believe on the Lord Jesus Christ, the virgin-born son of God, who died to take upon Himself the punishment for the sin of mankind, and who rose from the dead so that by receiving Him as Savior and Lord, man is redeemed by His blood.

2.4.1.5. That Jesus Christ will personally return to earth in power and glory.

2.4.1.6. That the Holy Spirit indwells those who receive Christ for the purpose of enabling them to live righteous and holy lives.

2.4.1.7. That the Church is the Body of Christ and is composed of all those who through belief in Christ have been spiritually regenerated by the indwelling Holy Spirit. The mission of the Church is worldwide evangelization and the nurturing and discipling of Christians.

(Board of Trustees, Resolution \#3, September 25, 1977. 